\title{
Outcome of COVID-19 associated severe ARDS: A case series
}

\author{
Vanada Talwar $^{1} \square$, Saurav Mitra Mustafi ${ }^{2} \square$, Arin Choudhury ${ }^{2} \square$, \\ Shruti Jain ${ }^{2} \bowtie$, Ajay Kumar ${ }^{2} \square$ \\ Authors' affiliations: \\ 1- Professor, Vardhman Mahavir Medical College and Safdarjung Hospital, New Delhi, India. \\ 2- Associate Professor, Vardhman Mahavir Medical College and Safdarjung Hospital, New Delhi, India.
}

Correspondence: Dr. Shruti Jain, Associate Professor, Vardhman Mahavir Medical College and Safdarjung Hospital, New Delhi, India; E-mail: shruti.anaesth@gmail.com; Phone: +91 9212308441

\section{Abstract}

ICU course may be prolonged in patients suffering from Coronavirus associated acute respiratory distress syndrome (CARDS) due to severity of initial disease and presence of opportunistic infections. A structured approach to management may help reduce morbidity and mortality. Case presentation: We present a series of five cases of CARDS with a prolonged ICU course, despite the resolution of viremia. A multipronged therapeutic approach was adopted in the form of self proning, thrombo-prophylaxis, chest physiotherapy, adequate nutrition, psychotherapy and early mobilization.

We could transfer two patients on domiciliary oxygen therapy and one on room air. Despite aggressive measures to control infection, one patient developed fungal sepsis, and another developed pseudomonal pneumonia. Both the patients rapidly deteriorated and succumbed to secondary infection, despite having shown initial recovery from CARDS. Conclusion: Prevention of infections is the key to recovery after resolution of viremia. This warrants COVID step down facility and structured rehabilitation program.

Key words: COVID-19; ARDS; Sepsis

Citation: Talwar V, Mustafi SM, Choudhury A, Jain S, Kumar A. Outcome of COVID-19 associated severe ARDS: A case series. Anaesth. pain intensive care 2021;25(2):199-202. DOI: 10.35975/apic.v25i2.1472

Received: 18 January 2021, Reviewed: 13 February 2021, Accepted: 25 February 2021

\section{Introduction}

Coronavirus disease-2019 (COVID-19) usually manifests as a mild or uncomplicated illness. Hospitalization rates vary widely, and 3\%-10\% of cases require admission to an intensive care unit (ICU). ${ }^{1}$ Some patients develop a life-threatening form of respiratory failure - acute respiratory distress syndrome (ARDS), which has a high mortality of $39 \% .{ }^{2}$ In such cases, the ICU course may be protracted due to the severity of initial disease and the presence of opportunistic infections. ${ }^{3}$ A structured approach to management may help reduce morbidity and mortality. We present a series of five cases of COVIDassociated ARDS (CARDS) with a prolonged ICU course, despite the resolution of viremia. Although multiple management regimes have been tried for COVID-19 in different parts of the world, it is essential to share our good or adverse experiences for a consensus to be reached.

\section{Case description}

During August 2020, five patients were admitted to the ICU of our tertiary care hospital, with CARDS (Table 1). The diagnosis of COVID-19 was made after the detection of severe acute respiratory syndrome 
coronavirus 2 (SARS-CoV-2) RNA by real-time polymerase chain reaction (RT-PCR). Mean age was $41.2 \mathrm{y}$ and three of the five patients were male. Three patients were diabetic and one presented in the immediate postpartum period. All cases presented with fever, cough and breathlessness with respiratory rate of 30-32 per min and the mean time from onset of symptoms to admission in ICU was 5.6 days. Inflammatory markers (interleukin-6, serum ferritin, D-Dimer) increased by three times or more in all patients and lung infiltrates occupied more than $50 \%$ of lung field on X-ray chest (Figure 1).

They were diagnosed with hypoxemic respiratory failure and the mean $\mathrm{PaO}_{2} / \mathrm{FiO}_{2}$ ratio at presentation was 144.2. They received intravenous (IV) methyl prednisolone $80 \mathrm{mg} \mathrm{BD}$ for 10 days which was gradually tapered off. ${ }^{4}$ All patients received $8 \mathrm{mg} / \mathrm{kg}$ IV tocilizumab, which was repeated after $24 \mathrm{~h}$. Antibiotics (piperacillin/tazobactam along with azithromycin), thrombo-prophylaxis with low molecular weight heparin, vitamin C, B complex and zinc were also added to the treatment. Random blood sugar was monitored for every patient every two hourly and subcutaneous inulin was given according to the sliding scale. Two patients each required noninvasive ventilation (NIV) and high flow nasal cannula (HFNC) while one required alternate NIV and non-rebreathing mask (NRBM) to maintain a $\mathrm{SpO}_{2}$ of more than $92 \%$. None of the patients were intubated. Self-proning of patients was encouraged.

The patients became negative for RT-PCR after a mean duration of 14.2 days. However, the oxygen requirement remained high and they were shifted to a non-covid ICU for further management at a mean $\mathrm{PaO}_{2} / \mathrm{FiO}_{2}$ ratio of 220.1. High resolution computed tomography (HRCT) of the chest revealed groundglass opacities, fibrosis, interlobular septal thickening and traction bronchiectasis.

All patients received dual oxygen therapy with nasal prongs and venti mask/NRBM, to improve oxygenation and decrease the rates of desaturation during feeding and incentive spirometry. A multifaceted therapeutic approach was adopted in the form of self-proning, thrombo-prophylaxis, chest physiotherapy, adequate nutrition, psychotherapy, and early mobilization (Table 1). Mean duration of steroids was 15.6 days. In addition, mean stay of patients in ICU was 30 days. Two patients succumbed to

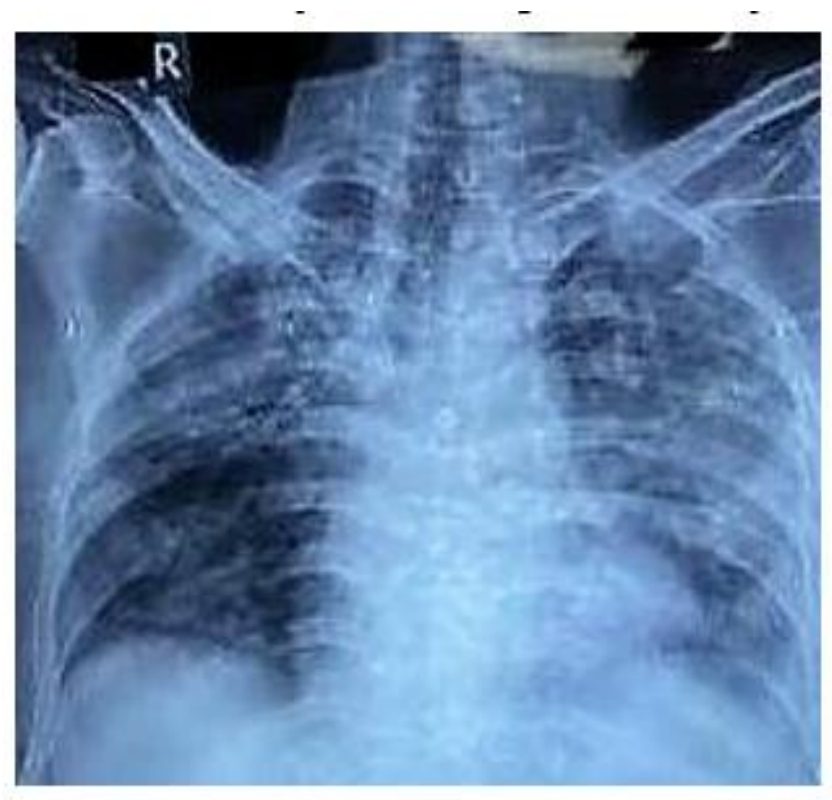

Figure 1: X-ray of patient on Day 1

opportunistic infections, one was discharged on domiciliary oxygen therapy, while two patients did not require oxygen at discharge.

\section{Discussion}

CARDS is associated with an inflammatory reaction characterized by destruction of the deep airway and alveoli. This lung injury is not only associated with direct virus-induced damage, but also the immune responses triggered by COVID-19 that lead to the activation of immune cells and release of significant pro- and anti-inflammatory cytokines. ${ }^{5}$ The leading cause of death in COVID-19 is severe acute respiratory syndrome which occurs due to an exacerbated inflammatory response along with uncontrolled oxidative stress. ${ }^{6}$ Therefore, diminishing the cytokine storm and initiating anti-inflammatory therapy during the correct time window is critical for reducing mortality in COVID-19. ${ }^{7}$ Mikulska et al recommended early adjunctive treatment with tocilizumab, methylprednisolone or both to improve outcomes in non-intubated patients with COVID-19 pneumonia. ${ }^{8}$ The primary anti-inflammatory action of corticosteroids is to repress a large number of proinflammatory genes, thereby dampening the cytokine storm and associated tissue injury. ${ }^{4}$ Tocilizumab is a recombinant monoclonal antibody against the interleukin-6 (IL-6) receptor, and is seen as a potential therapy for the cytokine storm syndrome associated with severe COVID-19. ${ }^{9}$ 
Though corticosteroids and tocilizumab prevent or limit lung damage in CARDS, they may increase susceptibility to secondary infections. Khilali $\mathrm{S}$ et al. opined that tocilizumab can be considered in patients with excessive lung inflammation or high IL-6 levels; though risk of sepsis remains a major challenge. ${ }^{10}$ Moreover, this combination also interferes with the interpretation of leucocyte count.

Poor pulmonary reserves in patients recovering from the severe acute phase (as revealed by the patients' HRCT reports), immunocompromised status (due to the presence of comorbidities, Covid 19 disease state and combination therapy of steroids and tocilizumab) and prolonged ICU stay all contribute to the risk of superadded infections. As a protocol, our patients were subjected to repeated cultures of body fluids and sepsis markers such as procalcitonin and galactomannan at regular intervals, to actively look for sepsis. Despite aggressive measures to control the infection, one patient developed fungal sepsis, and another developed pseudomonal pneumonia. Both the patients rapidly deteriorated and succumbed to secondary infection, despite having shown initial recovery from CARDS.

In addition to combating infection, a multifaceted approach in the form of early mobilization, chest physiotherapy, thrombo-prophylaxis, self-proning, adequate nutrition and psychotherapy was devised to

Table 1. Clinical features of Patients

\begin{tabular}{|c|c|c|c|c|c|}
\hline Variable & Patient 1 & Patient 2 & Patient 3 & Patient 4 & Patient 5 \\
\hline Age (y) & 56 & 44 & 24 & 56 & 26 \\
\hline Sex & Male & Male & Female & Male & Female \\
\hline BMI (Kg/m 2) & 25 & 30.8 & 31.5 & 28 & 26.3 \\
\hline Comorbidity & $\begin{array}{l}\text { Hypertension, } \\
\text { Type } 2 \text { Diabetes } \\
\text { Mellitus }\end{array}$ & $\begin{array}{l}\text { Type } 2 \text { Diabetes } \\
\text { Mellitus }\end{array}$ & Nil & $\begin{array}{l}\text { Type } 2 \text { Diabetes } \\
\text { Mellitus }\end{array}$ & $\begin{array}{l}\text { Post-partum with } \\
\text { portal cavernoma } \\
\text { of liver }\end{array}$ \\
\hline $\begin{array}{l}\text { Presenting } \\
\text { symptoms }\end{array}$ & $\begin{array}{l}\text { Fever, cough, sore } \\
\text { throat, } \\
\text { Breathlessness }\end{array}$ & $\begin{array}{l}\text { Fever, cough, sore } \\
\text { throat, } \\
\text { Breathlessness }\end{array}$ & $\begin{array}{l}\text { Fever, cough, } \\
\text { Breathlessness }\end{array}$ & $\begin{array}{l}\text { Fever, cough, sore } \\
\text { throat, } \\
\text { Breathlessness }\end{array}$ & $\begin{array}{l}\text { Fever, cough, } \\
\text { Breathlessness }\end{array}$ \\
\hline $\begin{array}{l}\text { Number of days } \\
\text { from initial } \\
\text { symptoms to ICU } \\
\text { admission }\end{array}$ & 6 & 5 & 5 & 10 & 2 \\
\hline $\begin{array}{l}\mathrm{PaO}_{2} / \mathrm{FiO}_{2} \text { ratio on } \\
\text { arrival in ICU }\end{array}$ & 125.5 & 167.7 & 115.5 & 127.9 & 184.5 \\
\hline $\begin{array}{l}\text { Inflammatory } \\
\text { markers on } 1 \text { st day } \\
\text { of ICU admission }\end{array}$ & $\begin{array}{l}\mathrm{IL}-6: 230 \mathrm{pg} / \mathrm{ml} \\
\text { Ferritin: } 895 \mathrm{ng} / \mathrm{ml} \\
\text { D-dimer: } 1439 \\
\mathrm{ng} / \mathrm{ml}\end{array}$ & $\begin{array}{l}\text { IL-6: > } 5000 \mathrm{pg} / \mathrm{ml} \\
\text { Ferritin: } 1160 \\
\text { ng/ml } \\
\text { D-dimer: } 744 \\
\text { ng/ml }\end{array}$ & $\begin{array}{l}\text { IL-6: } 285.48 \\
\text { pg/ml } \\
\text { Ferritin: } 522 \\
\text { ng/ml } \\
\text { D-dimer: } 20293 \\
\text { ng/ml }\end{array}$ & $\begin{array}{l}\text { IL-6: } 247.98 \mathrm{pg} / \mathrm{ml} \\
\text { Ferritin: } 149 \mathrm{ng} / \mathrm{ml} \\
\text { D-dimer: } 659 \\
\mathrm{ng} / \mathrm{ml}\end{array}$ & $\begin{array}{l}\text { IL-6: } 313 \mathrm{pg} / \mathrm{ml} \\
\text { Ferritin: } 1500 \\
\text { ng/ml } \\
\text { D-dimer: } 1874 \\
\text { ng/ml }\end{array}$ \\
\hline HbA1c value & 9.3 & 8.6 & 7.2 & 10.2 & 8.3 \\
\hline $\begin{array}{l}\text { Number of days } \\
\text { taken to become RT } \\
\text { PCR negative after } \\
\text { admission }\end{array}$ & 9 & 9 & 11 & 12 & 30 \\
\hline $\begin{array}{l}\mathrm{PaO} 2 / \mathrm{FiO} 2 \text { ratio on } \\
\text { arrival in Non covid } \\
\mathrm{ICU}\end{array}$ & 210.6 & 196 & 250 & 188 & 256.2 \\
\hline Total steroid days & 18 & 14 & 17 & 14 & 15 \\
\hline $\begin{array}{l}\text { Total Number of } \\
\text { days in ICU }\end{array}$ & 25 & 25 & 25 & 25 & 50 \\
\hline Outcome & Expired & $\begin{array}{l}\text { Discharged on } \\
\text { domiciliary oxygen } \\
\text { therapy }\end{array}$ & Expired & Discharged & $\begin{array}{l}\text { Discharged on } \\
\text { domiciliary oxygen } \\
\text { therapy }\end{array}$ \\
\hline
\end{tabular}

BMi: Body mass index

PaO2/FiO2 ratio: a ratio of arterial axygen portial pressure to fractional inspired oxygen 
accelerate recovery. Early mobilization and chest physiotherapy remain the cornerstone for pulmonary rehabilitation and prevention of infections. ${ }^{11.12}$ These measures helped us in transferring one patient without and two patients on domiciliary oxygen therapy. Step down from an ICU set-up not only aids in infection control, it also promotes overall well-being. Teleconsultation can further enhance monitoring, especially of patients who are discharged on domiciliary oxygen therapy. ${ }^{13,14}$

\section{Conclusion}

Though steroids and tocilizumab are helpful in overcoming cytokine storm of COVID-19, these should be used judiciously. The number of days of steroids should be kept minimal as prevention of infections is the key to recovery after resolution of viremia. A dedicated COVID step-down facility should be mandated in all COVID hospitals. There should be structured pulmonary rehabilitation program, adequate nutrition, psychotherapy and early mobilization of patients for post-COVID recovery. More data for post-COVID sequel by setting up national data registry may be warranted.

\section{Conflict of interest}

None declared by the authors.

\section{Authors' contribution}

VT: Concept, Conduction of Study work

SMM, SJ: Conduction of Study work, manuscript editing

AC, AK: Conduction of Study work

\section{References}

1. Mehta Y, Chaudhry D, Abraham OC, Chacko J, Divatia J, Jagiasi B, et al. Critical Care for COVID-19 Affected Patients: Position Statement of the Indian Society of Critical Care Medicine. Indian J Crit Care Med. 2020 Apr;24(4):222-241. [PubMed] DOI: 10.5005/jp-journals10071-23395

2. Chawla R, Nasa P. ventilatory management of covid19-related ARDS: stick to basics and infection control. Indian J Crit Care Med. 2020;24(8):609-610. [PubMed] DOI: $10.5005 /$ pp-journals-10071-23513

3. Raghu G, Wilson KC. COVID-19 interstitial pneumonia: monitoring the clinical course in survivors. Lancet Respir Med. 2020 Sep;8(9):839-842. [PubMed] DOI: 10.1016/S2213-2600(20)30349-0
4. Marik PE, Kory $P$, Varon J, Iglesias J, Meduri GU. MATH+ protocol for the treatment of SARS-CoV-2 infection: the scientific rationale. Expert Rev Anti Infect Ther. 2020 Aug 18;1-7. [PubMed] DOI: 10.1080/14787210.2020.1808462

5. Xu Z, Shi L, Wang Y, Zhang J, Huang L, Zhang C, et al. Pathological findings of COVID-19 associated with acute respiratory distress syndrome. Lancet Respir Med. 2020 Apr 1;8(4):420-2. [PubMed] DOI: 10.1016/S2213-2600(20)30076-X

6. Giménez VM, Inserra F, Tajer CD, Mariani J, Ferder L, Reiter RJ, et al. Lungs as target of COVID-19 infection: Protective common molecular mechanisms of vitamin $D$ and melatonin as a new potential synergistic treatment. Life Sci. 2020 May 15:117808. [PubMed] DOI: 10.1016/j.lfs.2020.117808

7. Zhang W, Zhao Y, Zhang F, Wang Q, Li T, Liu Z, et al. The use of anti-inflammatory drugs in the treatment of people with severe coronavirus disease 2019 (COVID19): The experience of clinical immunologists from China. Clinl Immunol. 2020 Mar 25:108393. [PubMed] DOI: $10.1016 /$ j.clim.2020.108393

8. Mikulska M, Nicolini LA, Signori A, Di Biagio A, Sepulcri $C$, Russo $\mathrm{C}$, et al. Tocilizumab and steroid treatment in patients with COVID-19 pneumonia. Plos one. 2020 Aug 20;15(8):e0237831. [PubMed] DOI: 10.1371/journal.pone.0237831

9. Zhang S, Li L, Shen A, Chen Y, Qi Z. Rational Use of Tocilizumab in the Treatment of Novel Coronavirus Pneumonia. Clin Drug Investig. 2020;40(6):511-518. [PubMed] DOI: 10.1007/s40261-020-00917-3

10. Khiali S, Khani E, Entezari-Maleki T. A comprehensive review of tocilizumab in covid-19 acute respiratory distress syndrome. J Clin Pharmacol. 2020 Sep;60(9):1131-46. [PubMed] DOI: 10.1002/jcph.1693

11. Gosselink R, Clerckx B, Robbeets $C$, Vanhullebusch $T$, Vanpee G, Segers J. Physiotherapy in the intensive care unit. Neth J Crit Care. 2011 Apr 1;15(2):66-75. [FreeFullText]

12. Thomas P, Baldwin C, Bissett B, Boden I, Gosselink R, Granger CL, et al, Ntoumenopoulos G, Parry SM, Patman S, van der Lee L. Physiotherapy management for COVID-19 in the acute hospital setting: clinical practice recommendations. J Physiother. 2020 Apr;66(2):73-82. [PubMed] DOI: 10.1016/j.jphys.2020.03.011

13. Wright $\mathrm{JH}$, Caudill R. Remote treatment delivery in response to the COVID-19 pandemic. Psychother Psychosom. 2020 Mar 26;89(3):130-2. [PubMed] DOI: 10.1159/000507376

14. American Psychiatric Association, American Telemedicine Association. Best practices in videoconferencing-based telemental health. 2018. Available from: https://www.psychiatry.org/File\%20Library/Psychiatrist s/Practice/Telepsychiatry/APA-ATABest-Practices-inVideoconferencing-BasedTelemental-Health.pdf 